\title{
An Unknown 1859 Notaries' Ledger from Douglas County, Kansas
}

\section{M.H. Hoeflich*}

One of the advantages of being a legal historian is the need and pleasure to search out documents relevant to one's research no matter where they may be. During my early career, when I focused on the history of Roman and medieval legal history, these searches took place primarily in museums and archives, often in rather wonderful places such as Paris, Rome, and the Vatican. When I began teaching law in the U.S. and researching American legal history at the University of Illinois College of Law, I found myself visiting obscure small towns in central and southern Illinois searching out letters and documents for the Lincoln Legal Papers Project. ${ }^{1}$ When I moved to the University of Kansas School of Law in 1994, I decided to begin to research Kansas legal history. Over the past two decades this research has led to a number of published papers as well as a book on the history of the Federal District Court in Kansas. ${ }^{2}$ Over the years that I have been doing research on Kansas legal history, I have not only scoured all of the available libraries and archives in the state relevant to the subject, but I have also made it a habit to attend estate auctions and book sales which might contain relevant unknown materials. I have had a number of successes in these outings, including the discovery of a one volume diary kept by Kansas Supreme Court Justice Daniel Mulford Valentine ${ }^{3}$ which contained the only known contemporary manuscript account of Abraham Lincoln's visit to and speech at Leavenworth, Kansas in 1859.

\footnotetext{
* John H. \& John M. Kane Distinguished Professor of Law, University of Kansas. B.A., M.A., Haverford College; M.A., Ph.D., Cambridge University; J.D., Yale Law School; LL.D. (h.c.), Baker University.

1. I had the pleasure to serve as a consultant to the Lincoln Legal Papers Project from 19851987. To learn more about the project, see Abraham Lincoln Presidential Library \& Museum: Papers of Abraham Lincoln, ILlINOIS.GOv, https://www.illinois.gov/alplm/library/lincoln/Pages/ PapersofAbrahamLincoln.aspx (last visited Apr. 4, 2018).

2. See Michael H. Hoeflich, Justice on the Prairie: 150 Years of the Federal DISTRICT COURT OF KANSAS (2011).

3. See M.H. Hoeflich \& Virgil W. Dean, "Went at Night to Hear Hon. Abe Lincoln Make a Speech” Daniel Mulford Valentine's 1859 Diary, KAN. Hist., Summer 2006, at 100, 100 n.1, 102 (describing how the diary was discovered and its account of attending Lincoln's speech).
} 
I have sometimes described what pushes me to attend country estate auctions and book sales, often in terrible weather, eating bad barbeque and forced to use unventilated porta-potties, as an addiction similar to the need to gamble or drink potent spirits. Certainly, my addiction to book and manuscript hunting has damaged my financial health as much as alcohol might damage one's liver, but the fact is, so long as I continue to find books and manuscripts that help me to write the history of Kansas law, I will be getting in my car and heading out for rural sales always with the hope of making a new discovery. ${ }^{4}$

Thus, early in the morning on a rather warm late spring day in 2013, I drove over to attend an auction in Tonganoxie, Kansas. The auction advertisement mentioned that there were manuscript diaries from Douglas County for sale. This, in itself, was reason enough for me to attend. When I arrived, I discovered that this was no ordinary auction. Instead, it was an auction of the collections of Jan Shoemaker, a long time auctioneer in this area. Over the years that she and her late husband had conducted their auction business, they had collected numerous items, particularly items relating to Kansas. The auction was at the small house that Jan Shoemaker owned and was selling, along with most of the contents, because she was moving out West to retire. I asked where the diaries were. I was shown to the garage where there were several boxes of printed and manuscript materials. I found the diaries, I found correspondence, and I found something that literally took my breath away. In one of the boxes was a small book, covered in marbled paper of the type commonly sold during the Civil War period. When I opened it up to discover its contents, my eye was caught by the following inscription at the top of the second ruled sheet ${ }^{5}$ :

Record of the acts of D.B. Kimball—Notary Public for Douglas County, Kansas Territory.

The first entry was for 5 July 1859! This was an amazing find, one quite the equal to any of my previous discoveries.

The volume that I found at that time measures 6.5 inches by 7.5 inches. It consists of forty-six sheets of lined paper plus a front free

4. I have written elsewhere about the importance of luck and chance, serendipity, in doing history, see Michael H. Hoeflich, Serendipity in the Stacks, Fortuity in the Archives, 99 LAW LIBR. J. 813 (2007). For those readers intrigued by this phenomenon, I also recommend ARLETTE FARGE, THE AlluRE OF THE ARCHIVES (Thomas Scott-Railton trans., Yale Univ. Press 2013) (1989).

5. A scanned copy of the notary ledger that is the subject of this article accompanies the electronic version of this article at: https://law.ku.edu/kansas-law-review-issues\#. 
endpaper. Of these, a total of twenty-six and one half sheets contain notarial entries dating from 5 July 1859 to 22 November 1860 . The entries dating from 5 July to 14 September 1859 were made by D.B. Kimball. The entries from 18 January 1860 to 22 November 1860 were made by A.A. Smith. The remainder of the volume consists of several blank sheets, a number of sheets containing household accounts from the $1860 \mathrm{~s}$ and 1870s and some miscellaneous notes. The volume itself is bound in marbled paper with a leather spine. One entry in the household accounts suggests that the volume continued to be in Douglas County after 1860 since it records payment of a bill to Ridenour and Baker, retail merchants in Lawrence. ${ }^{6}$

The survival of this volume to the present day is, itself, quite remarkable and may be a result of the owners' unwillingness to follow the Kansas statute that regulated notaries and the records of their official acts. Chapter 101 of the 1859 Kansas Statutes provided for the appointment of notaries public and for the disposition of the records of their official acts. ${ }^{7}$

\section{CHAPTER CI.}

AN ACT respecting Notaries Public.

Be it enacted by the Governor and Legislative Assembly of the Territory of Kansas:

SECTION 1. The governor shall appoint and commission in each county, as occasion may require, one or more notaries public, who shall hold their offices for four years.

SEC. 2. They may receive the proof or acknowledgment of all instruments of writing relating to commerce and navigation, receive and authenticate acknowledgments of powers of attorney, make declarations and protests, and certify the truth thereof under their official seals, concerning all matters by them done by virtue of their offices, and shall have all the powers and perform all the duties of register of boatmen.

SEC. 3. Every notary shall keep a fair record of his official acts, and, if required, shall give a certified copy of any record in his office, upon the payment of the fees therefor.

SEC. 4. If any notary die, resign, be disqualified or remove from the county, his record and official and public papers of his office shall, within thirty days, be delivered to the register of deeds of the county, to be delivered to his successor when qualified.

SEC. 5. Every notary shall provide a notarial seal, containing his

6. See James C. Horton, Peter D. Ridenour and Harlow W. Baker, Two Pioneer Kansas Merchants, in 10 COllections of the Kansas State Historical Society, 589, 601-02 (1908) (describing the merchants' business in Lawrence prior to Quantrill's raid).

7. See Act of Feb. 3, 1859, ch. 101, §§ 1-11, 1859 Territorial Session Laws of Kansas. 
name, and place of residence, and he shall authenticate all his official acts, attestations and instruments therewith.

SEC. 6. Every notary public, before entering on the duties of his office, shall take the oath of office prescribed by law, which shall be indorsed on his commission, and shall give bond to the Territory of Kansas in the sum of five hundred dollars, with good securities, conditioned for the faithful performance of the duties of his office.

SEC. 7. Such bond, commission and oath shall be recorded in the register's office of the county, and the bond shall be filed in the office of the secretary of the Territory, and may be sued on by any party injured.

SEC. 8. No suit shall be instituted against any such notary or his securities more than three years after such cause of action [accrues.]

SEC. 9. Notaries public shall have authority to administer all oaths provided for by law, and to take the acknowledgement of deeds and other instruments of writing, conveying or affecting lands or other property in any part of this Territory.

SEC. 10. All acknowledgements heretofore taken by notaries public of deeds or other instruments, conveying or affecting lands out of the county in which such notary resided, are hereby confirmed and made valid, if otherwise correct.

SEC. 11. This act to take effect and be in force from and after the first day of June next.

A. LARZALERE, Speaker of the House of Representatives. C. W. BABCOCK, President of the Council.

Approved February 3, 1859.

S. MEDARY, Governor. ${ }^{8}$

Section 3 of Chapter 101 requires that "[e]very notary . . . keep a fair record of his official acts." Section 4 of Chapter 101 requires that when a notary dies, resigns, or is disqualified from office or moves from the county in which he holds his appointment, he shall deliver to the county Register of Deeds "his record and official and public papers" so that they can be delivered to his successor. ${ }^{10}$ This may well have occurred at the end of Mr. Kimball's service as notary in 1859, but, presumably, it did not happen at the end of Mr. Smith's term of office since the volume stayed in private hands as witnessed by the later household entries. However, this small legal infraction by Mr. Smith may well have been the reason that the volume survived at all. Official documents from

\footnotetext{
8. Id.

9. Id. at $\S 3$.

10. Id. at $\S 4$.
} 
Douglas County before 1863 are quite rare because most were destroyed in 1863 when Lawrence was attacked and burned during a raid led by William Quantrill. ${ }^{11}$ According to Andreas' History of the State of Kansas, one effect of Quantrill's raid was to destroy the county records. ${ }^{12}$

Notaries Public have been minor government officials at least since the time of the Romans and have always played a role in the AngloAmerican Common law. ${ }^{13}$ Fundamentally, the role of the notary is to authenticate documents and to take oaths from individuals. In the words of the current Kansas Notary Public Handbook:

The purpose of a notary public is to prevent fraud and forgery. The notary acts as an official, unbiased witness to the identity of the person who signs the document. A Kansas notary public has six major duties:

1. Take acknowledgments,

2. Administer oaths and affirmations,

3. Take a verification upon oath or affirmation,

4. Witness or attest a signature,

5. Certify or attest a copy, and

6. Note a protest of a negotiable instrument. ${ }^{14}$

As is obvious, the duties have changed little from Chapter 101, Section 2 of the 1859 Statutes, quoted above, until today. ${ }^{15}$

The 1859 provision on notaries called for the appointment by the Governor of notaries for each county who were to serve a four-year term. ${ }^{16}$ Each was required to post a $\$ 500$ bond and to swear an oath. ${ }^{17}$ The bonding requirement illustrates the critical role that notaries played in the territory. Among notaries' duties the most important was acknowledging documents, particularly the transfer of deeds and mortgage executions. ${ }^{18}$

11. See William Elsey ConNelly, Quantrill and the Border Wars 284-395 (1910) (describing the "Lawrence Massacre").

12. See A. T. Andreas, History of the State of Kansas 311 (1883) (citing a journal entry by the County Commissioner describing how the "county house" and most county records were destroyed in the raid).

13. See generally C. W. Brooks et al., Notaries Public in England Since the Reformation (1991); C. R. Cheney, Notaries Public in England in the Thirteenth and FOURTEENTH CENTURIES (1972)

14. Kan. SeC'y of State, Kansas notary Public Handbook 4 (2016), https://www.kssos.org/forms/administration/book.pdf.

15. See supra notes $7-14$ and accompanying text.

16. Act of Feb. 3, 1859, ch. 101, § 1, 1859 Territorial Session Laws of Kansas.

17. Id. at $\S 6$.

18. In the Territory it was usually either a notary or a Justice of the Peace who would 
The significance of the acknowledgement function to territorial financial transactions and law derives from the simple fact that land transactions, deed transfers and mortgage executions were the mainstay of the Territorial economy. Effectively during the Territorial period, settlers came to Kansas for three reasons: (1) to acquire farm land; (2) to establish residency in order to vote to keep Kansas a "free state" (i.e. to bar slavery in the eventual state); (3) to speculate on the value of land. ${ }^{19}$ All three required a system for effective land transfer and financing. In fact, Kansas Territory had a booming economy in land transactions ${ }^{20}$ and was, therefore, especially vulnerable to fraudulent transactions. In Douglas County the federal land office was established at Lecompton in 1855 after Lecompton had been designated the "seat of government" for the Kansas Territory. ${ }^{21}$

Land transactions in the Kansas Territory were quite complex because of several factors. First, much of the Territorial land had been granted to Native American tribes who had been removed from the East. $^{22}$ But Eastern white immigrants wanted the Indian lands which required that these lands be taken from the tribes and made federal land subject to grant to white settlers. ${ }^{23}$ Once land had been categorized it was available for sale to settlers pursuant to the Preemption Law of 1841, which permitted individuals already illegally on land to acquire that land by "preemption" by paying the federal government for it. ${ }^{24}$ Individuals

acknowledge deed transfers and mortgage executions. Act of Feb. 8, 1859, ch. 87, § 2, 1859 Territorial Session Laws of Kansas ("That justices of the peace... shall have jurisdiction and authority ... [t]o take the acknowledgement of deeds, mortgages and other instruments of writing . . .."). See also generally Ruth Y. Wetmore, The Justice of the Peace in Kansas (1960). My examination of several of the Deed Register volumes dating from 1857-1862 now held by the Douglas County Register of Deeds bears out this observation. These Register volumes contain the entirety of the deeds with acknowledgements and roughly half of the deeds in these volumes were acknowledged by notaries and the other half by Justices of the Peace. See infra note 31.

19. See Paul E. Wilson, How the Law Came to Kansas, in Musings Of A SMiLing Bull 77, 87-94 (Paul E. Wilson ed., 2000) (discussing reasons for settlement, the importance of land transactions, and the legal complications involved during the territorial period in Kansas).

20. See Michael H. Hoeflich, The Lawyers of Old Lecompton, in TALLGRASS ESSAYS: PAPERS FROM THE SYMPOSIUM IN HONOR OF DR. RAMON POWERS 29 (Michael H. Hoeflich, Gayle R. Davis \& Jim Hoy eds., 2003) [hereinafter Hoeflich, Lawyers] (describing the rapid pace at which towns were being established during this time period).

21. Albert R. Greene, United States Land-Offices in Kansas, in 8 TRANSACTIONS OF THE Kansas State Historical Society 1, 3 (Geo. W. Martin ed., 1904). See also generally The PUBlic LANDS: A BRIEF SKETCH IN United STATES HistoRy (1963) (describing the history of the General Land Office and management of public lands in the United States).

22. See WiLSON, supra note 19 , at 81,88 .

23. See id. at $87-89$.

24. See id. at 88 (describing preemption generally and how most Indian lands were eventually opened to non-Indian settlement by preemption or purchase). 
could also purchase tracts of land from "Township Companies" that purchased large tracts of land and then subdivided them and sold them to individuals. $^{25}$ These and other complexities led to a rise of quasi-legal "claims associations" which adjudicated land disputes in parallel to the federal land office. ${ }^{26}$

Given the legal complexity of land transactions and the potential for fraudulent claims and litigation, it is easy to understand the need for professionals like notaries, Justices of the Peace, and lawyers. ${ }^{27}$ Furthermore, the population of the Kansas Territory was always in flux. Settlers would come to one place and often move to another within the Territory. Often out-of-staters, particularly Missourians, would come to Douglas County for short periods and then return to Missouri. ${ }^{28}$ The net result of all of this movement meant that it would be difficult for land dealers or mortgage lenders to assure the identities of the parties with whom they were dealing. The acknowledgement process, which required the parties to swear to their identities under oath, provided some protection, therefore, against identity fraud. ${ }^{29}$

Chapter 101, Sec. 1 of the 1859 Statutes specifies that the Governor of the Territory had the authority to appoint "one or more" notaries in each county. ${ }^{30}$ Not surprisingly, there were quite a few working notaries in Douglas County during the territorial period. The Deed Record volumes currently held by the Register of Deeds for Douglas County record in full the deeds registered during the territorial period. During the period for which the volume being described in this article was used by Kimball and Smith, I counted among the notarial acknowledgements in the Deed Record Book for 1859-1860 a substantial number of names of notaries, including David T. Mitchell, E.D. Ladd, J.K. Goodin, H.K. Simpson, Henry Still, James M. Hendry, John M. Croc, David G. Peabody, E. Victor, Louis Green, and John Hill. ${ }^{31}$ The simple number of

\footnotetext{
25. William E. Treadway, The Gilded Age in Kansas, 30 KAN. Hist. Q. 1, 2 (1974).

26. WILSON, supra note 19, at 90-94.

27. On the legal profession in territorial Douglas County, see generally id. at 100-04; Paul E. Wilson, John Adams Halderman: Our Eldest Brother, in Musings OF A SMILING Bull 125 (Paul E. Wilson ed., 2000) (describing the experiences of an early, prominent Kansas lawyer). On the legal profession in territorial Lecompton, see generally Hoeflich, Lawyers, supra note 20.

28. See Nicole Etcheson, BleEding Kansas 31 (2004) (describing how Missourians "freely crossed the border" to participate in Kansas's affairs but did not settle there permanently).

29. For an interesting example of how acknowledgement by a notary was used to guarantee the authority of an author's signature, see Stephen Enniss, In the Author's Hand: Artifacts of Origin and Twentieth-Century Reading Practice, 2 RBM 106, 108-09 (2001).

30. Act of Feb. 3, 1859, ch. 101, § 1, 1859 Territorial Session Laws of Kansas.

31. See Douglas County Register of Deeds Record Book D, available electronically at
} 
notaries listed in the Deed Record book testifies to the amount of demand for notarial services in Douglas County during this period.

Although the volume under discussion does not contain the full texts of the notarial acknowledgements made, the full texts of these acknowledgements are contained in the Deed Record Books now at the Douglas County Register of Deeds. The following is the text of the acknowledgement used by A.A. Smith on 28 June 1860 and illuminates the actual notarial process:

Territory of Kansas

Douglas County

Personally came before me a Notary Public, in and for the said County of Douglas this $28^{\text {th }}$ day of June A.D. 1860 . Wilson Shannon and Sarah Shannon wife of the said Wilson Shannon to me personally known to be the identified persons described in and who executed the above conveyance and severally acknowledged the instruments to be their voluntary act and deed. And the said Sarah Shannon wife of the said Wilson Shannon on an examination apart from her said husband, having first been made acquainted with the content of such conveyance acknowledged that she executed the same and relinquished her dower in the real estate therein mentioned freely and without any fear or compulsion of her said husband. In Testimony Whereof I have hereunto set my hand and affixed my notarized seal this day and year above written.

$$
\begin{array}{ll} 
& \text { A.A. Smith } \\
\text { NL.S. } & \text { Notary Public }
\end{array}
$$

The description of the notarial verification process contained in this passage illustrates the care territorial notaries took to insure not only that the signatories to legal documents were who they claimed to be ["to me personally known"], but, also, that the documents, if they involved the transfer of rights or property, were entered into freely by the parties. In this example, Sarah Shannon's dower rights in the underlying property were going to be extinguished. ${ }^{33}$

\footnotetext{
Douglas County Courthouse, Lawrence, Kansas. Interestingly, two of the notaries named were also used extensively to take oaths by H.J. Strickler when he conducted his inquisition to take claims for damages suffered during the territorial period in Kansas. See H.J. Strickler, Claims of the Citizens of the Territory of Kansas, H.R. Misc. Doc. No. 35-43, at 254, 601 (1858) (showing claims notarized by E.D. Ladd and David T. Mitchell). For more on these, see M.H. Hoeflich \& William Skepnek, Claims for Loss in Territorial Kansas, 65 U. KAN. L. REV. 711 (2017).

32. Record Book D, supra note 31 , at 415.

33. Dower was the property right accorded by law to a widow in her husband's property.
} 
Unfortunately, I have not been able to find any detailed biographical information on either Kimball or Smith. The Kimball family was a prominent industrial family in Lawrence at this time, and there were three brothers who owned and operated the Kimball Brothers Foundry. ${ }^{34}$ However, none of the three brothers had the initials "D.B" and Andreas in his History of Kansas does not provide a biography for or otherwise list a "D.B. Kimball." "There is a listing of a "D.B. Kimball" in the 1859 Kansas Territorial Census, which states that he lived in Lecompton Township but provides no further information. ${ }^{36}$ And while there were a number of "Smiths" listed in the Territorial Census of 1855-1859, I could not find an "A.A. Smith" anywhere. ${ }^{37}$

Although I was unable to find any biographical information or place of residency for Smith, there are some hints in the volume itself as to where in Douglas County he may have resided. A significant number of the deed transactions that are recorded in the volume are transfers of land from the Lecompton Township Association to various individuals. Presumably, these transactions would have occurred in Lecompton, and therefore Smith, like Kimball, may have been based in or near Lecompton. A second indication that Smith lived and worked near Lecompton when he served as a notary is his acknowledgements of documents that involved Wilson Shannon. Shannon was a prominent Douglas County lawyer who served for a short term as Territorial Governor and who carried on a law practice first in Lecompton and then in Lawrence. ${ }^{38}$

Another interesting aspect of the volume are the fees recorded. Kimball did not record the fees he received for his work. A.A. Smith,

Joseph F. English, Married Women and Their Property Rights: A Comparative View, 10 CATH. U. L. REV. 75, 84 (1961).

34. William G. Cutler, History of the State of Kansas: Douglas County, Part 14, Kansas COLLECTION BOOKS, http://www.kancoll.org/books/cutler/douglas/douglas-co-p14.html (internet version of Cutler's book published in 1883, mentioning brothers Edward, Franklin, and Samuel) (last visited Apr. 27, 2018); see also ANDREAS, supra note 12, at 339 (disclosing brief biographies of Franklin and Samuel Kimball).

35. See id.

36. KANSAS 1859 (Ronald Vern Jackson ed., 1988) (listing "D.B. Kimball" at page 209).

37. For 1855 census data, see TERritorial Census IndeX, KANSAS, 1855 (Ronald Vern Jackson ed., 1977). For 1856-1858 census data, see Kansas State Census 1856-1858, microformed at Reel 1 No. 11,636 (Univ. of Kan. Libraries). For 1859 census data, see KANSAS 1859 (Ronald Vern Jackson ed., 1988). The censuses are also available through the Kansas State Historical Society's Interlibrary Loan Program, https://www.kshs.org/p/1855-1859-kansas-territorycensuses/10960.

38. Hoeflich, Lawyers, supra note 20, at 32; see also ANDREAS, supra note 12, at 113 (discussing Wilson Shannon's early career and personal life). 
however, did. Chapter 68, Section 11 of the 1859 Statutes established the fees to be charged by Kansas notaries:

For each protest and record of the same, seventy-five cents; for each notice of protest, fifty cents; taking an acknowledgement, fifty cents; taking depositions, the same fees as justices of the peace [35 cents, per Chapter 68, Section 7]; taking an affidavit, twenty-five cents.

Between 18 January and 22 November 1860, A.A. Smith recorded eighty-three separate notarial acts. Of these, thirteen were affidavits; the remainder were acknowledgements. Interestingly, in a number of cases, Smith charged one dollar for an affidavit or acknowledgement. If one ignores these occasional exceptions, Smith would have earned $\$ 38.25$ for his year's work as a notary based on the entries. Even with the occasional charge beyond the statutory amount, Smith would have earned only a bit above $\$ 40$ during that year. While not negligible, this would not have been a sufficient income alone. To give some notion of the "purchasing power" we can look at the prices for household goods in 1864-1865 listed later in the volume. One can of coffee cost \$1.40. One and one-half pounds of tea cost $\$ 3.00$. One peck of potatoes was fifty cents. Two pounds of candles cost $\$ 1.00$. One box of yeast powder cost $\$ 1.00$. One half pint of brandy cost seventy cents. One bottle of Hostettlers Bitters cost $\$ 1.25$. A bedstead cost $\$ 6.50$ and a gallon of kerosene cost $\$ 1.75$. A newspaper cost ten cents. A day laborer earned $\$ 15 /$ month. Thus, it seems likely that these notaries also had other sources of income. Occasionally it would appear that the client did not pay the fee at all. On 9 June 1860 Smith recorded: "Swore S.W. Driggs to three affidavits and got not a damned cent." Some problems never change.

One of the most interesting questions raised by the survival of the notarial acts record which I discovered and have described in this article is the question of who the rightful owner is today. When I purchased it I did so in the knowledge that I would, in fact, donate it to the proper library or historical association. But as I did the research for this article, I realized that the volume is an official record and, under the 1859 Statutes should have been returned to the Douglas County clerk when Smith's term in office expired so that it could be handed to his successor, just as Kimball presumably did so that Smith could use it. The fact that

39. Act of Feb. 11, 1859, ch. 68, § 11, 1859 Territorial Session Laws of Kansas. 
Smith disobeyed the law and failed to return the volume to the clerk did not cause the volume to cease to be public property. Thus, as public property it belongs either to the State of Kansas or to Douglas County. On the other hand, the volume has been in private hands since 1860 and, had Smith not violated the 1859 Statute ordering the return of the book, the book itself would not have survived but, rather, been burned with all of the other public documents during Quantrill's Raid in 1863. To solve this conundrum, I did what any law professor would do. I contacted the office of the Attorney-General of the State of Kansas for an opinion. One day after I phoned, I received a telephone call back from an extremely helpful and bright Assistant Attorney-General. Her reasoning, in my opinion, was impeccable. Because the volume dates from before Kansas became a state, the State of Kansas does not have a claim to pursue to acquire ownership of the volume. In her opinion, the best claimant would be Douglas County which existed at the time the 1859 Statutes were enacted and the clerk of whom was delegated to receive the volume. Therefore, I contacted the Douglas County Administrator, Craig Weinaug who stated that were I willing to donate the volume to the County, the County would donate it in turn to the Kansas Collection, which already holds most of the territorial manuscripts from Douglas County. I agreed. And, thus, this newly discovered territorial record of a notary's acts will soon be available to the public to view at the Kansas Collection housed at the Spencer Rare Book Library at the University of Kansas. 